\title{
INFORMAČNÍ CHOVÁNÍ ČESKÝCH A SLOVENSKÝCH STUDENTU゚ V OBDOBÍ PANDEMIE COVID-19
}

Mgr. Michaela Dombrovská, Ph.D.; michaela.dombrovska@fpf.slu.cz; (Ústav bohemistiky a knihovnictví, Filozoficko-př́rodovědecká fakulta, Slezská univerzita v Opavě)

PhDr. Pavol Rankov, PhD.; pavel.rankov@uniba.sk; (Katedra knižničnej a informačnej vedy, Filozofická fakulta, Univerzita Komenského v Bratislave)

Ústav bohemistiky a knihovnictví Filozoficko-prírodovědecké fakulty Slezské univerzity v Opavě ve vzájemné spolupráci s Katedrou knihovní a informační vědy Filozofické fakulty Univerzity Komenského v Bratislavě uskutečnili srovnávací výzkum informačniho chování vysokoškolských studentů v čase pandemie a lockdownů. Sběr českých dat byl umožněn v rámci interní studentské grantové soutěže na Slezské univerzitě (SGS/2/2021), a to formou online dotazníků s otevřenými otázkami s důrazem na vlastní sebereflexe respondentů, sběr dat na Slovensku byl podpořen Agentúrou na podporu výskumu a vývoja na základě smlouvy APVV-19-0074. Srovnání výsledků ukazuje, že zkušeností studentů z různých zemí jsou navzdory upravené metodě, časovému odstupu a různé míre záběru respondentů velmi podobné a poukazují především na nároky, limity, ale také otevřené možnosti online vzdělávání.

https://doi.org/10.52036/1335793X.2021.3-4.7-14

ÚVOD

Ústav bohemistiky a knihovnictví Filozoficko-přírodovědecké fakulty Slezské univerzity v Opavě ve vzájemné spolupráci s Katedrou knihovní a informační vědy Filozofické fakulty Univerzity Komenského v Bratislavě uskutečnili srovnávací výzkum informačního chování a informační gramotnosti vysokoškolských studentů $v$ čase pandemie a lockdownů. Sběr českých dat byl umožněn $v$ rámci interní studentské grantové soutěže na Slezské univerzitě (SGS/2/2021) využívající účelové podpory na specifický vysokoškolský výzkum, na kterém spolupracovala studentka 4. ročníku navazujícího magisterského studia knihovnictví Lucie Valjentová, a navazoval na obdobný výzkum uskutečněný na Slovensku pod vedením Pavla Rankova, který proběhl v ríjnu 2020 mezi vysokoškolskými studenty (Rankov 2021b) a byl podpořen Agentúrou na podporu výskumu a vývoja na základě smlouvy APVV-19-0074. Ten se zaměřoval na informační chování a obecně životní podmínky v době lockdownu, včetně dojmu z distančního studia, a probíhal kvalitativní metodou retrospektivní eseje. Mezi hlavní výsledky slovenského výzkumu přitom patří zvýšený zájem o aktuální zpravodajství mezi studenty, zvýšená míra používání digitálních technologií a online komunikace, a s tím spojené zdra- votní (mentální i fyzické) problémy, změny v informačním chování v online prostředí, obavy z dezinformací a dopady na reálné mezilidské vztahy - což jsme obdobně předpokládali také $v$ českém prostředí.

Studie, které se zaměřovaly na dopady pandemie na studenty a vysokoškolské studium, se začaly objevovat už v průběhu roku 2020. V ČR zatím podobný výzkum prímo zaměřený na informační chování studentů neproběhl, i když oblast zkoumání se částečně překrývá s mezinárodním výzkumem COVID-19 International Student Well-being Study, který realizovala Antverpská univerzita v roce 2020 a kterého se zúčastnili studenti sedmi českých veřejných vysokých škol (ČzU, MU, UHK, UK, UPOL, UTB a VŠE). Jedná se o mezinárodní výzkumnou iniciativu, která se ve spolupráci s 27 zeměmi zaměřila na vysokoškolské studenty a na to, jak se jich pandemie koronaviru dotkla v oblasti studií, duševní pohody a dalších príbuzných témat. Sběr dat probíhal online od 28. 4. do 19. 5. 2020. Už to, že mezi univerzitami a fakultami panoval značný rozdíl v přístupu $k$ řešení výpadku prezenční výuky, mělo vliv na studenty pocitovanou míru studijního zatížení a stresu. Pokud byl výpadek prezenční výuky kompenzován ve větší míre online výukou než osobním studiem nebo online výukou a osobním studiem ve stejné míre, bylo zatížení a stres studentů nižší než v prípadě, 
kdy byl výpadek více kompenzován nárůstem osobního studia než online výukou (Akademie věd 2020a). Jinak jsou zatím k dispozici spíše částečné výsledky, studie se zaměřovala na změny $v$ životním stylu nebo finanční situaci, na změny $v$ př́stupu ke studiu (Rabiee -Khan \& Biernat 2021) a mimo jiné také kuprríkladu na hodnocení zdrojů informací; ve finském prostředí až $70 \%$ studentů považovalo za relevantní převážně oficiální zdroje informací (Kappe 2021).

Dopady pandemie na mentální zdraví studentů se však projevily po celém světě (Superio a kol. 2021; viz také Rankov 2021a). Z faktorů, které se podílely na informačním přetížení a z toho plynoucí informační úzkosti, studie potvrdily jako významný faktor sociální sítě (Soroya a kol. 2021), a to jako arénu střetu nejrůznějších názorů, především však sloužící k obhajobě vlastního názoru a potvrzení takového názoru $v$ rámci vlastní informační bubliny (Glasdam \& Stjernswärdb 2021). Jako zdroj informací jsou však sociální sítě vnímány s rezervou, za ověřené respondenti většinově stále považují spíše oficiální zdroje informací (Skarpa \& Garoufallou 2021), mezi které se řadí také knihovny. Knihovny se v pandemické době, podobně jako školy, vyrovnávaly se skokovou změnou požadavků na výuku, včetně kurzů zaměřených na informační gramotnost, a uchovaly si svůj status relevantního a nezávislého zdroje informací (Guo \& Huang 2021). Mohly se rovněž podílet na sdílení aktuálních doporučení, které směřovaly k podpoře mentálního zdraví (Király 2020). Mezi taková doporučení přitom často patřilo právě omezení času tráveného online (screen time; Riehm a kol. 2020). V ČR taková doporučení vydával např́klad Psychologický ústav Akademie věd (Akademie věd 2020b); Národní ústav duševního zdraví zahájil několik výzkumů v souvislosti s pandemií a spustil např́klad projekt Opatruj.se (Národní ústav 2021).

Aktuálně v ČR probíhá také dotazníkové šetření Ministerstva školství, mládeže a tělovýchovy (MŠMT ČR), které se mimo jiné zaměřuje na spokojenost s př́stupem a komunikací školy a zkušenosti s distanční výukou, připravenost vyučujících na distanční výuku a problémy, kterým studenti čelí (včetně například rezignace na vyšší míru aktivity ve studiu nebo ukončení studia) (MŠMT ČR 2021); výsledky pro porovnání však zatím nejsou dostupné.

\section{METODOLOGIE VÝZKUMU}

Ve stávající výzkumné sondě byl jako výzkumná procedura použit dotazník, avšak pouze s otevřenými otázkami, čím ho řadíme na pomezí kvalitativních a kvanti- tativních metod. Otázky měly charakter širších okruhů, ke kterým se měli respondenti vyjádřit vlastními slovy ve formě ucelených rozsáhlejších písemných výpovědí. Tuto metodiku jsme volili i s vědomím rizika, že někteří respondenti budou na některé otázky odpovídat lakonickými „ano“ či „ne“. Cílem bylo navodit u respondentů volný tok myšlenek.

Výzkumná sonda byla realizována prostřednictvím emailové výzvy a dotazníkové aplikace Google Forms v měsících červen až červenec 2021 (konec semestru absenční výuky v období protipandemických opatření). Z 69 oslovených studentů se zapojilo 26, což znamená $38 \%$ (minimálním požadavkem přitom byla účast 20 studentů). Ze zúčastněných byli 4 muži a 22 žen, 21 studentů bakalářského a 5 studentů magisterského (navazujícího) studia na Filozoficko-přírodovědecké fakultě Slezské univerzity v Opavě. Dotazníkový formulář obsahoval 6 otázek ve formátu širších tematických okruhů, které byly zaměřeny tak, aby odpovědi mohly být komparovány se dvěma staršími výzkumnými šetřeními slovenských studentů zaměřenými na analogická témata. První ze slovenských výzkumných sond byla realizována kvalitativní metodou retrospektivní eseje, ve které respondenti odpověděli na otázku Jak se změnila úloha sociálních sítí a obecně internetu v mém životě v průběhu první vlny pandemie na jaře 2020. Respondenti tuto esej psali s několikaměsíčním odstupem od prvního lockdownu $v$ době relativního uvolnění v zárí 2020. Výzkumný vzorek tvořilo 55 respondentů - 36 žen a 19 mužů, všichni byli studenty bakalářského stupně na Filozofické fakultě Univerzity Komenského v Bratislavě. Druhé zkoumání slovenských studentů se uskutečnilo v dubnu až květnu 2021 metodou strukturovaného online rozhovoru s 8 respondenty -4 muži a 4 ženy, z toho 7 studentů magisterského stupně a 1 student 4. ročníku bakalářského stupně z různých slovenských vysokých škol.

Stávající dotazníkové šetření opavských studentů spojuje se slovenskými výzkumy jeho autobiograficko-reflexivní zaměření založeno na relativně volném toku vzpomínek, což umožňuje respondentům individuální a subjektivní přístup $\mathrm{k}$ odpovědím na bázi vlastních názorů i formulací. Tento typ narací je způsobem rekapitulace minulé zkušenosti prostřednictvím propojování diskurzivních praktik přítomnosti se sociálními praktikami minulosti (Labov 1999, cit. dle Bočák 2009, s. 130).

Korpus textů z „českých“ dotazníků, "slovenských“ esejí a rozhovorů (resp. jejich písemných přepisů) 
obsahoval sémiotická data, která jsme vyhodnocovali prostřednictvím textové a diskursní analýzy. Analyzovali jsme přitom nikoliv pouze jednotlivé izolované výpovědi, ale tyto výpovědi v kontextu jiných (všech) výpovědí. V souladu s postupem, který pro kvalitativní obsahovou analýzu navrhují Elo a Kyngäs (2008), jsme v prvním kroku zpracovali narativy respondentů a podrobili je otevřenému kódování. $V$ druhém kroku jsme zjištovali shody, podobnosti a odlišnosti v naracích respondentů, abychom na základě obsahové príbuznosti mohli vytvořit vyšší celky (kategorie). Ve třetím kroku jsme abstrahovali rysy diskurzu na základě převládajících obsahů. Až syntézou všech získaných narací se vynořil celý diskurz jako verbální objekt (vyřčený či zapsaný text), ale i mentální reprezentace.

Je téměř jisté, že respondenti ve svém sociálním prostředí na "ožehavé" téma výzkumu mezi sebou komunikovali už před realizací výzkumu. Proto jednotlivé zaznamenané výpovědi odrážejí „živý“ diskurz existující $v$ dané době a prostředí, i když některé narace mohou $s$ převládajícím diskurzem polemizovat. Naše interpretace zjištění vychází prrímo $z$ textů respondentů, proto uvádíme i delší citace, které zpravidla reprezentují celou skupinu podobných názorů. Pokud jde o postoj výjimečný, vždy na to upozorňujeme. Citace ze slovenských narací zůstaly ve slovenštině. Texty respondentů přinášíme v jejich původním znění, tj. citace odpovědí z dotazníků a esejí mohou obsahovat chyby, vyjádření z rozhovorů mohou obsahovat stylistické nedokonalosti nekorigované mluvené řeči.

\section{VÝSLEDKY VÝZKUMU}

První otázkou dotazníku jsme sledovali, jak se vyvíjel zájem respondentů o aktuální informace a zpravodajství před pandemií, během první vlny na jaře 2020 a ve fázi uvolnění začátkem léta 2021. Většina respondentů potvrdila, že s nástupem pandemie se zvýšil jejich zájem o aktuální informace, avšak s přibývajícím časem tento zájem postupně klesal, až se vrátil na úroveň před pandemií.

$\checkmark$ první vlně se můj zájem o informace zvětšil o $100 \%$ a zhruba do začátku třetí vlny (cca leden letošního roku) tento zájem prétrvával. Dnes už je v oběhu moc dezinformací a už to nesleduji. (žena, Bc.)

Před pandemií jsem se o aktuální informace zajímala rozhodně méně, než po jejím začátku. Během první vlny jsem hodně sledovala (dá se ř́ci denně) její vývoj, nová nařizení... V současnosti zájem mírně polevil. (žena, Mgr.)

Určitě jsem se začala zajímat více o politiku, zdravotnictví a s tím související zdroje, které jsem předtím ne- vyhledávala. (žena, Bc.)

Během první vlny covidu na jaře 2020 jsem aktivně sledovala zpravodajství, jak v televizi, tak na internetu ... $V$ současnosti již informace ohledně pandemie aktivně nesleduji. (žena, Bc.) Během první vlny pandemie se můj zájem o informace (zejména COVID-19) zvýšil. Dalo by se ríci, že zpravodajství ČT jsem sledovala každý den, vyhledávala jsem také informace na internetu apod. Postupem času můj zájem o média polevil. (žena, Mgr.)

$\checkmark$ první vlně jsem zprávy sledovala častěji. Postupně jsem se od nich odkláněla čím dál více, v současnosti se na zprávy nedivám vůbec, informace nevyhledávám. (žena, Bc.)

...není to už nic nového než bylo pred rokem, tehdy jsem se tedy určitě zajímala více. (žena, Bc.)

Na začátku pandemie jsem sledovala zprávy každý den, ted' už skoro vübec. (žena, Bc.)

...ze začátku mě to hodně zajímalo, postupně můj zájem o tuto problematiku slábl a nyní se rovná takřka nule. (muž, Bc.)

...už tolik zpravodajství o covidu nesleduji ... i z toho důvodu, že to je už "dlouho" a je únavné snažit se být pořád v obraze. (žena, Bc.)

$\checkmark$ první vlně... ve snaze být informován se stalo mým rituálem sečkávání na uveřejnění vývoje čísel souvisejících s pandemií. ... V současné době se o pandemii zajímám daleko méně. (muž, Bc.)

Eseje slovenských respondentů (psané v záŕí 2020) potvrzují velký zájem o aktuality v první vlně pandemie, dokonce někteří potvrzují ritualizaci každodenního sledování určitých statistik.

Ja som napríklad nepretržite každý deň pozeral na webe čísla ohl'adom prebiehajúcej situácie.

(muž, Bc.)

Každý deň som sledovala aktuality.sk, či denník SME a s rodinou čakala na nové správy od hygienikov alebo vlády. Predtým som vôbec nepozerala každý večer správy, ale teraz som situáciu deň čo deň aktívne sledovala. (žena, Bc.)

...som bol nútený sledovat na sociálnych sietach profily Ministerstva zdravotníctva SR a Úradu verejného zdravotníctva. Zároveň som si nastavil príspevky spomenutých inštitúcií ako prioritné. (muž, Bc.)

Televízne noviny a špeciálne zasadnutia vlády sme sledovali nonstop. (žena, Bc.)

Prvé dni sme sledovali živé vysielania na facebooku, či iných internetových stránkach o d'alšom postupe. Zo dn̆a na deň sme dostávali nové informácie. (žena, Bc.)

„Vd'aka" pandémii sme viacej počúvali alebo čítali 
informácie zo slovenského parlamentu a ministerstva školstva. O túto oblast' som sa nikdy predtým nezaujímala. (žena, Bc.)

V rozhovorech (z jara 2021) už slovenští respondenti poukazují na klesající zájem o nové informace a částečně i znechucení z toho, že v médiích už dlouho dominuje téma pandemie.

Prišla pandémia a l'udia odvtedy začali sledovat' kol'ko je nakazených, kol'ko sa uzdravilo, kol'ko l'udí zomrelo. Ale už to opadlo a už je toho na mňa privel'a. (muž, Mgr.)

Teraz už sa mi to ani nechce sledovat.' (žena, Mgr.)

Je to plné koronaopatrení, kto, kam, čo, kedy môže, cestovanie, vychádzanie, testovanie.

(muž, Mgr.)

Zo začiatku to bolo nové, všetci sme sa zaujímali o čísla, aké sú $v$ tej ktorej krajine. Teraz sa $v$ tom nevyznám. Tento rok som nepozerala vôbec televízor... Ked' niečo neviem, tak sa rodičov opýtam. (žena, Mgr.) Pozriem si kol'ko ludí je v nemocniciach, kol'ko je nakazených, teda aká je situácia, ale že by som to vyslovene vyhl'adával, sa nedá povedat'. Už je toho na mňa privel'a. L'udia sú z toho unavení, podl'a mňa. (muž, Mgr.)

Jedna respondentka ukazuje na přechod od intenzivního zájmu o aktuální informace směrem k pragmatickému př́stupu.

...přestala jsem sledovat televizi a $v$ internetových zdrojích hledám kdy, co a jak. $V$ první vlně jsem sledovala vše. $V$ letošní jen to nejnutnější k životu. (žena, Bc.)

$U$ jedné respondentky se $v$ první vlně pandemie objevila i jistá forma informačního zahlcení a stresu, vưči kterým si však našla své řešení.

$\checkmark$ první vině jsem byla ze všech médií zmatená a ztrácela jsem se v tom. Časem jsem začala sledovat instagramový účet Dominika Feriho, ve kterém jsem se líp orientovala, hlavně díky jeho vykřičníküm. (žena, Bc.)

Vysoký zájem o nové informace z první vlny však přetrval jenom zcela výjimečně.

Před pandemií jsem se nijak zvlášt' o aktuální informace a zpravodajství nezajímala. Začala jsem se zajímat právě při první vině pandemie a $v$ současnosti se zajímám nejvíce. (žena, Bc.)

Ve druhém tematickém okruhu v rámci dotazníku jsme se respondentů ptali, zda začali $v$ důsledku lockdownu používat nějaké nové aplikace, technologie nebo online služby, př́padně zda začali některé technolo- gie používat za jiným účelem než před lockdownem. Pochopitelně se ukázalo, že největší nárůst zájmu zaznamenaly služby a aplikace umožňující videohovory a chat. Značný podíl na tom má i nástup online výuky. Uzávěra knihoven vyvolala u studentů nevyhnutelný nárůst zájmu o databáze a digitální knihovny.

...Skype, Messenger, Google Meet. Také aplikace pro komunikaci se školou MS Teams a Google Classroom... jsem začal vnímat problém v množství emailových adres (několik školních, pracovnich a osobnich emailů), a tak jsem některé propojil se svojí hlavní emailovou adresou. (muž, Bc.)

Začala jsem používat nástroje pro komunikaci, např. MS Teams, Zoom, Google Meets (pro online hodiny ve škole). Více jsem využivala sociální sítě (facebook, instagram), hlavně z důvodu komunikace s práteli. (žena, Bc.) Kvưli škole jsem začala využívat aplikace na virtuálni schůzky, jako napr. Microsoft Teams, Google meetings, Whereby a Zoom ... Začala jsem více využivat možnost nákupu pres internet.

...Zoom, Whereby, videohovory přes Facebook. (žena, Bc.)

...jsem poprvé vyzkoušela kupovat oblečení přes internet s dovážkou domů. Byla jsem velmi mile překvapena, takže to budu využívat i nadále. (žena, Bc.)

Zkusila jsem aplikaci e-rouška, po měsíci jsem zjistila, že $v$ mém okolí jsem snad jediná, nikdo ji nepoužíval. (žena, Bc.)

Začal jsem ve velké míre využivat e-zdroje, vzdálený přistup a digitální knihovnu Kramerius.

(muž, Bc.)

...začala jsem díky lockdownu více využívat digitální knihovnu, El zdroje. (žena, Mgr.)

$Z$ důvodu uzavření knihoven, jsem začala využívat ndk. cz., ke studiu používám MS Teams. V práci se různá školení přesunula do online prostředí. (žena, Bc.)

...Zoom, MS Teams (konference, přednášky) a Google meet, přes který jsme dělali s práteli a rodinou online setkání. (žena, Bc.)

Tento pochopitelný vývoj plně potvrdili i slovenští respondenti ve svých esejích. U nich jsou však zajímavější spíše ty způsoby využívání technologií, které propojují mezilidskou online komunikaci s jinými aktivitami. ...streamovacie služby ako Netflix či $H B O$, ktoré mi dokonca umožňovali sledovat' danú epizódu či film v tom istom čase ako priatel'ka či priatel', pričom sme zdiel'ali spoločný chat ktorý nám suploval atmosféru v kine. (muž, Bc.)

$S$ priatel'om som cez videohovor volávala niekol'ko hodín, často sme tieto hovory využivali ako „podmaz" pri iných činnostiach ako upratovanie, va- 
renie či učenie. Raz sme dokonca na dial'ku spoločne pozerali film... Aj s kamarátmi sme si pisali ovel'a dlhšie správy alebo posielali hlasové správy. Niekedy sme využili aj skupinové hovory. Toto sme predtým nikdy nerobili. (žena, Bc.)

$S$ kamarátmi sme si plánovali pravidelné online stretnutia, počas ktorých sme si zavolali, zapli videokamery a dokonca sme mohli hrat' aj hry. (žena, Bc.)

Spočiatku sme hrávali s kamarátmi hry na počítači, s tým, že sme sa rozprávali, každý večer, že ako sa majú ako prežívajú karanténu. (muž, Bc.)

Hoci som nikdy predtým hry nehrala, zrazu si z môjho dňa dokázali odkrojit' poriadne vel'ký kus času. Bol to jeden zo spôsobov, ako sme s priatel'om spolu trávili čas. Osobné stretnutia sme boli nútení preniest' do online prostredia, kde sa zrazu namiesto Lucie a Sandra stretávali online postavičky Lunalix a Gurtmog. (žena, Bc.)

Zrazu sme všetci a všetko kupovali online. Ja som tiež podl'ahla nezmyselnému nakupovaniu oblečenia, ktoré som nemala komu predviest', lebo som sedela doma. Online nakupovanie využívam stále a od vypuknutia pandémie som $v$ „kamennom" obchode kúpila len minimum vecí. (žena, $B c$.)

...čo sa zmenilo bolo online nakupovanie. Tomu som predtým nefandila... Za kratši čas si viem prezriet' viacero obchodov a porovnat' ceny. Karanténa ma tiež prinútila predplatit'si Netflix. (žena, Bc.)

Nárůst využivání služeb pro videohovory potvrdili i respondenti v rozhovorech.

„Nové nie, ale intenzívnejšie to áno... s kamarátmi tie videohovory. Zoom, Discord, Meet.

(muž, Mgr.)

Parciálním tématem, které vyplynulo z našeho výzkumu, se ukázal být i vzájemný průnik fyzických aktivit a digitálních technologií. $U$ českých respondentů to byly digitální doplňky kontrolující pohyb, u slovenských zase cvičení u počítače.

Pořídila jsem si fit náramek s GPS a začala jsem si hlídat pohybovou aktivitu. (žena, Bc.)

...jsem na Vánoce dostala chytré hodinky, jsem začala více sledovat svůj pohyb a spánek.

(žena, Bc.)

...som vymenila beh a posilňovacie stroje za cviky z fitness videí na YouTube. Zistila som, že cvičenie doma mi vyhovuje, a aj po skončení karantény som s tým pokračovala. (žena, Bc.)

$S$ priatel'om sme sa mohli porozprávat' vd'aka Messengeru a cez videohovory. Prvé mesiace sme pretelefonovali hodiny a hodiny. Dokonca sme sa rozhodli začat cvičit. Ja pred mojim počítačom doma a on pred svojim. (žena, Bc.)

...s priatel'om sme spolu cvičili cez videohovor na messengeri. (žena, Bc.)

...pozerat' live stream, počúvat' podcast, cvičit' jogu cez skupinu v MS Teams. (žena, Bc.) Moja trénerka z fitness centra poskytovala hodiny tabaty naživo na Facebooku. (žena, Bc.) Zaujímali ma najnovšie seriály, nové videá na cvičenie zverejňované na Youtube. (žena, Bc.) Folklórny súbor... sme začali vysielat' tréningy online. Prvýkrát v živote som tancovala sama v obývačke pred počítačom s kamerou. (žena, Bc.)

Jednotlivé respondentky a respondenti užívali digitální nástroje i pro jiné specifické a jedinečné účely. ...jsem např́klad měl distančně hru na klavir, která samozřejmě nemůže plně nahradit prezenční výuku. (muž, Bc.)

...som každý týždeň na instagramovom profile učila dievčatá mal'ovat'sa pomocou live prenosu. Ukazovala som základné lićenia a vel'a kamarátiek aj cudzích žien mi napisalo, že sú mi vd'ačné. (žena, Bc.)

...som mala rozbehnutý účet na sociálnej sieti s umeleckými fotkami, a ked'že moji sledovatelia boli vd'aka karanténe aktívnejší, prihovorila som sa k svojmu publiku a vysvetlila som moju finančnú situáciu. Podarilo sa mi oslovit' ludí, ktorí si začali kupovat moje umenie, a zabezpečila som si tak aspoň minimálny príjem. (žena, Bc.)

...som si kúpila nový Ipad, zakúpila som si i ilustračný program Procreate a začala som sa učit ilustrovat' podl'a videí z internetu. (žena, Bc.)

...sme prvýkrát v živote slávili Vel'kú noc z domu. Bol to zvláštny zážitok prejst' z izby do obývačky, obliect' sa pekne a pozerat' slávenie najväčšieho krest'anského sviatku cez live stream. (žena, Bc.)

Ako veriaci človek som musel prijat' fakt, že nedel'nú svätú omšu musím sledovat' z gauča mojej obývačky. (muž, Bc.)

Zjištovali jsme i pocity a dojmy respondentů související s distančním studiem, jak se s online přednáškami a semináři vyrovnali oni, jejich spolužáci, prípadně učitelé. Části respondentů distanční vzdělávání prostě nevyhovovalo, což znovu platí pro zjištění z dotazníků i esejí.

Online studium mi nevyhovuje. Jsem ze staré školy. (žena, Bc.)

...se s ním spíše peru, online přednášky jsou vyčerpávající, taktéž některé pisemné úkoly. Při prezenční výuce je možnost větši interakce s přednášejícím. (žena, Bc.) Online studium bylo neosobní a informace zde podá- 
vány byly někdy až strojově podávány.

(muž, Bc.)

...když si to člověk osahá na mistě a hned se zeptá když něčemu nerozumí, tím nemyslím že pres email by to nešlo, ale "naživo" to je jednodušší a príméjší. (žena, Bc.)

Více mi vyhovuje prezenční studium, z důvodu, že online výuka je pro mě stresující (nefunguje počítač, nastanou problémy, chybí osobní kontakt atd.)... Už jsou $z$ toho všichni unavení a těší se na návrat do školy. (žena, Bc.)

...chýbal nám kontakt so spolužiakmi pri vypracovávani spoločných zadaní ... skúšky online, ktoré boli omnoho mätúcejšie a stresujúcejšie ako písomný test. (žena, Bc.)

Tieto hodiny online si nikto nepochval'oval, nemali takmer žiadnu hodnotu a každý študent v mojom okolí prízvukoval, ako je prezenčná forma štúdia dôležitá. (muž, Bc.)

Stejně si na online výuku stěžovali i respondenti v rozhovorech.

Cítim sa byt ovel'a unavenejšia, ako ked'som chodievala do školy, lebo takto to je taký stereotyp. (žena, Mgr.) Mne to príde, že to je čím d'alej, tým t'ažšie. (žena, Mgr.) Nejak sme si na to zvykli, ale aj tak frfleme, že by to bolo lepšie osobne. (muž, Mgr.)

Jasné, vrátila by som sa do školy, ale to je asi zrejmé u každého. (žena, Mgr.)

Vtedy som sa potešil, ale časom to opadlo a radšej by som sa vrátil do školy ako byt' stále doma. Volím prezenčné štúdium pred dištančným. (muž, Mgr.)

Obecně respondenti uváděli zejména problematický nástup distančního vzdělávání na jaře 2020. Zpočátku byl problém $s$ domluvou s pedagogy a také ve zorientování se v nové aplikaci MS Teams... nyní vše funguje v pořádku. (žena, Mgr.)

...v první vlně jsme pořádně nevěděli co a jak, bylo to nové, museli jsme zkoušet nové věci. $V$ současnosti je to více rutinní a už víme, co máme dělat. (žena, Bc.)

Rozdíl vidím $v$ tom, že v první vlně nastalo hodně nových změn, takže jsme se všichni seznamovali s distanční výukou (jak bude probihat, za jakým podmínek...). V současnosti už to máme zažité. (žena, Bc.)

Změnu ve výuce jsem zaznamenala, $v$ první vlně to bylo vše nové, všichni jsme se seznamovali sonline výukou a bylo potreba se to naučit. Nyní to už každý bere "automaticky". (žena, Mgr.)

Slovenští respondenti, kteří psali své eseje v září 2020, měli jarní přechod na online vzdělávání ještě $v$ živé paměti stejně jako prvotní technické problémy, a naopak - neměli za sebou žádnou delší pozitivní zkušenost $s$ rutinní online výukou. Proto jsou jejich opisy mnohem kritičtější a dramatičtější.

Zo dňa na deň a z týždña na týždeň boli študenti aj učitelia nútení prejst' na úplne iný typ výučby. Bolo to obdobie chaosu, rovnako ako pre študentov, tak aj pre vyučujúcich. (muž, Bc.) Neustále ma bombardovali emaily od vyučujúcich s informáciami o výučbe, zadaniach, bodových ohodnoteniach či "deadlinoch". Zovšadial' vyskakovali pripomienky na prednášky, ktoré sa mali čochvil'a začat', či na zrušené prednášky, pri ktorých nasledovali emaily od vyučujúcich a $v$ nich sa nachádzali pokyny. (muž, Bc.)

Prednášky, ktoré prebiehali online, boli častokrát plné technických problémov. (žena, Bc.) Nebolo jednoduché si v prostredí domova zabezpečit' vhodné podmienky pre online prednášky či testovanie... som mala často nutkanie venovat' sa na internete, alebo celkovo počítači niečomu inému. Počas online prednášok som bola neraz vyrušovaná upozorneniami zo sociálnych sietí. (žena, Bc.)

Výrazným problémem distanční výuky je, že studenti se neumí soustředit na přednášku či seminář v domácím prostředí, co se potvrdilo $\vee$ českých dotaznících i slovenských esejích.

Mě osobně přechod na distanční výučbu nejdřive nevadil, protože nemusím denně strávit několik hodin $v$ dopravě... Postupně jsem si začala uvědomovat, že je studium takto těžší, je těžší se soustředit ... Mí spolužáci to myslím měli podobně. (žena, Bc.)

Problémy s internetovým pripojením byly leckdy také velmi rušivé. S tím souviselo i zhoršené soustředění. (žena, Bc.)

...od kamarádů vím, že se při distanční výuce nedokáží soustředit. (žena, Mgr.)

Dištančná výučba sa mi zo začiatku javila ako výhra, no po niekol'kých týždňoch za počítačom som zistila, že to tak nie je. Je t'ažké sústredit' sa na prednášku v domácom prostředí. (žena, Bc.)

Táto forma vyučovania mne osobne nevyhovuje, preferujem prezenčnú výučbu, pri ktorej sa na mňa l'ahšie lepia informácie a nemám problém s koncentráciou a udržiavaním pozornosti počas prednášok, čo sa pri výučbe cez internet povedat' nedá. (žena, Bc.)

Mnoho študentov, vrátane mňa, si začalo vážit školu, hlavne jej priestory, ... pretože vyučovanie cez internet nie je vel'mi efektívne, nie je ani praktické a t'ažko sa nan̆ sústredí....

A so spolužiakmi je predsa len viac zábavy. (žena, Bc.) ...multitaskingovej nesústredenosti. Popri tom, ako som sledoval školskú prednášku online som na vedlaj- 
šom monitore pracoval na zadaní. Z čoho následne vyšlo, že som ani v jednej veci nebol poriadne. (muž, Bc.)

A stejné názory zaznívaly i v průběhu rozhovorů. Myslel som si, že online vyučovanie bude dobré a budem viacej doma, ale po krátkom čase som názor zmenil. Osobný kontakt chýba a doma ma to netiahne sa ist' učit'. (muž, Mgr.)

Jako největší výhody online vzdělávání studenti zpravidla uvedli, že se tím šetří čas a peníze, protože nemusí dojiždět do školy. Takové důvody jsou však sekundární, bez souvislosti s kvalitou vzdělávání.

Distanční výuka mi naprosto vyhovovala, a to především díky úspoře času (dojižzění) a financí... Nechyběl mi sociální kontakt se spolužáky. Ale vím, že většina spolužáků preferuje kontaktní výuku. (žena, Bc.)

Výhody tady bych zmínila jen ušetřený čas, kdy bych musela príijet do školy. (žena, Bc.)

Mezi „pro" bych zařadila, že nebylo potřeba dojiždět. Člověk musel hlavně zvládnout vstát, upravit se, najist a pripojit se. (žena, $B c$.)

Za plus považujem, že nemusím ráno vstávat' a cestovat' do školy. (žena, Bc.)

Tato "ekonomicko-ekologická" pozitiva distančního vzdělávání se vyskytla i v rozhovorech.

...akurát to, že nemusíme chodit' do školy, máme ušetrený čas a peniaze spojené s dochádzaním. (žena, Mgr.)

Nemusím cestovat' do školy... Vstanem 10 minút pred konzultáciou. (žena, Mgr.)

Značná část českých respondentů měla větší či menší výhrady $\mathrm{k}$ online výuce zejména $z$ toho důvodu, že nesaturuje jejich psychologickou potřebu vzdělávání jako sociální aktivity a mezilidského kontaktu.

Distanční studium má pro mne dvě velké plus, a tím jsou úspora času a financí za dojiždění. Ale protože mám ráda sociální kontakt, mnohem raději bych investovala čas i peníze do osobního setkávání - prezenčního studia. (žena, Bc.)

Na distanční výuku jsem si rychle zvykla a vyhovuje mi více, než klasická prezenční. I když mi sem tam chybí sociální kontakt s kolegy a pedagogy. (žena, Bc.)

Mě osobně online výuka vyhovovala...Chyběl osobní kontakt.. (žena, Mgr.)

Chyběl mi pouze osobní kontakt s lidmi obecně, než prímo prezenční výuka. (muž, Bc.)

...chybí mi kontakt se spolužáky a vyučujícími, přednášky pres internet nejsou úplně ideální.

(žena, Mgr.)

...všem taky scházela ta prítomnost ve třídě... mi už dlouho vadí, že jsem jen doma. Mám pocit, že až to skončí, nebudu pomalu vědět, jak mluvit s lidmi. Chyběli mi spolužáci a i ty cesty autobusem. I to, jak jsem se ráno chystala do školy, vybírala, co si obleču. (žena, Bc.) Moc mi chybí osobní kontakt s pedagogy i se svými spolužáky. Chybí mi navzájem si pomáhat v hodinách a i motivace. (žena, Bc.)

Ve dvou prípadech respondentky srovnávaly online a prezenční vzděláváním i se vstupováním do jejich intimní zóny. Zajímavé přitom je, že jejich hodnocení bylo přesně opačné. Jedna respondentka má špatné pocity z kamery a monitoru ve svém soukromí, ta druhá zase oceňuje svou „neviditelnost" na distanční výuce.

Online výuka v prostředí MS Teams mi byla nepríjemná, jako by zasahovala do mé intimní zóny. $V$ posluchárně je mezi vyučujicím a studenty, i mezi studenty navzájem, větší odstup. Nehledína sebe neustále zblíz$k a$, tvárí v tvár. (žena, Bc.)

Ešte výhoda je, že... sa nepozerá ten učitel' priamo na mňa. (žena, Bc.)

Skutečně racionálně zhodnotilo klady online výuky jen několik respondentů.

Osobně bych uvítala kombinaci prezenční a online výuky, mnohdy online výuka je názornější než kontaktní, může být bleskově využito online zdrojů. (žena, Bc.)

Tato forma distančního studia mi vyhovovala, přednášky jsme si mohli nahrávat, takže jsem se k nim mohl kdykoliv vrátit. (muž, Bc.)

$\checkmark$ dalším okruhu $v$ dotazníku jsme se respondentů ptali, zda registrují vliv pandemie na dezinformace a hoaxy ve společnosti. Téměř jednoznačně poukazují na nárůst množství dezinformací a hoaxů na sociálních sítích a internetu obecně.

...v době pandemie se abnormálně navýšilo množství hoaxu a dezinformací. (žena, Mgr.) Zprvu byl můj zájem o informace docela veliký, ale postupem času začal upadat, protože se objevovalo více a více dezinformací a nepravdivých údajů. (žena, Bc.)

Díky pandemii si hodně všímám toho, že různé pochybné weby využívaji toho, že si lidé neumí ověřovat informace a pouští do světa různé hoaxy či dezinformace. Bohužel tomu lidé věří, vyvolávají paniku. (žena, Bc.) ...již tak politicky rozdělená společnost $v$ našem státě, se začala štěpit ještě podstatně více a hlavně kvưli fake news a hoaxům. (muž, Bc.)

Hoaxy a dezinformace tak rozděluji lidi na dva tábory. Mnohdy vznikají nenávistné hádky.

(žena, Bc.)

Dopad je tedy jednak negativní (přibylo množství dez- 
informací), ale také pozitivní (jsme nuceni informace více ověřvat). (žena, Bc.)

Úplně stejné jsou i reakce slovenských studentů získané prostřednictvím esejí.

...príchod skutočne obrovského množstva hoaxov, konšpiračných teorií, falošných správ, všetci boli zrazu vyštudovaní virológovia alebo imunológovia... l'udia, pri ktorých by som to vôbec nečakal, reálne šíria nebezpečné dezinformácie, hoaxy a konšpiračné teórie z pofidérnych webových stránok. (muž, Bc.)

Denne som zachytával, ako sa niektoré dezinformácie širili prostredníctvom sociálnych médií. Vel'a l'udí taktiež rozvijalo diskusie, ktoré by sme mali nechat' na odborníkov. (muž, Bc.) Dezinformácie sa šírili, konkrétne po sieti Facebook, odkedy si pamätám, ale väčšinou ich bolo jednoduché odignorovat'... Od marca nie je pred nimi úniku. (žena, Bc.)

Sociálne siete sa stali hlavným šíritel'om misinformácií, hoaxov a konšpiračných teórií.. Po vyhlásení celoštátnej karantény okrem kuchárov a umelcov sociálne siete zaplavili samozvaní lekári, vedci, ekonómovia, politickí analytici a odborníci na výživu. (muž, Bc.)

...dezinformácie otriasli internetom aj sociálnymi sietami pričom nie je také jednoduché proti nim bojovat' ako je jednoduché im podl'ahnút'. (muž, Bc.)

I rozhovory přinesly stejná stanoviska respondentů.

Strašne sa rozšírili hoaxy... Kvôli hoaxom som musela vymazat' aj zopár známych zo sociálnych sietí. (žena, Mgr.)

Každá druhá veta na Facebooku je dezinformácia... Ja si z Facebooku už neberiem nič, pre mňa to má nulovú hodnotu. (žena, Mgr.)

Zajímavé v této souvislosti je i to, že se někteří respondenti pokusili o zdůvodnění príčin nárůstu hoaxů či o chronologii vztahu společnosti a hoaxů.

Lidé byli během pandemie více doma, vyhledávali informace, které často nedokázali správně zpracovat a interpretovat, z čehož vznikaly fámy, hoaxy a poplašné zprávy. Této skutečnosti si byli vědomi i tvưrci hoaxů, kteří pochopitelně zvýšili svojí aktivitu. (muž, Bc.)

$\checkmark$ první vině pandemie jsme všichni věrili informacím, které zněly z televizí a mediálních zpráv

- nikdo jsme nevěděli, s čím se potýkáme. Ve druhé vlně se však začali širrit jiné informace, protože se začalo pricházet na to, s čím jsme se setkali. Na konci druhé vlny však bylo tolik informací, že člověk již nevěděl, čemu má věrit, a tak si každý začal budovat názor vlastní. Tím začaly vznikat další dezinformace... kdyby $v$ tuto dobu nebyly informační technologie, koronavi- rus by nebyl tak velkou krizí, jako to média vybarvila. (žena, Bc.)

Dezinformace a hoaxy byly ve společnosti již dríve, ale $s$ vývojem pandemie je jich možná daleko více. Je to možná zapřičiněno tím, že s vývojem pandemie došlo k masivnějšímu využívání internetu. (žena, Bc.)

Podobný názor zastávali i dva respondenti v rozhovorech.

Ja si myslím, že pomerovo je ich [dezinformácií] stále rovnako... iba l'udia to viac začali vnímat'. (muž, Mgr.) Vždy boli nejakí konšpirátori a vždy budú, len teraz mám pocit, že ako l'udia sú viac na internete a na sociálnych siet'ach, tak to viac vyplávalo na povrch. Je to na rovnako, ale predtým sa to nejako extra neriešilo, nevidelo. (muž, Mgr.)

V dalším okruhu jsme se $v$ dotazníku respondentů ptali, zda se $v$ důsledku pandemie a lockdownu změnil jejich prístup k sociálním sítím a obecně k informačním technologiím, a pokud $k$ takové změně došlo, jak se to projevuje. Prakticky všichni respondenti deklarovali určitou formu či aspekt kvalitativního růstu svoji informační gramotnosti. Z pravidla studenti více ověřují důvěryhodnost zdrojů nebo omezují svůj čas na sociálních sítích.

... více si hlídám, kdo článek napsal a zda je informace pravdivá. (žena, Mgr.)

Více si ověřuji informace. (žena, Bc.)

...rozhodně se změnil pohled na důvěryhodné zdroje. (žena, Mgr.)

Změnilo se, že jsem si začala více ověřovat zdroje a informace. (žena, Bc.)

...jsem se utvrdila $v$ tom, že je důležité si informace ověřvat, prověřvat... nestrávit $v$ sekci komentárú jejich čtením přiliš času, protože je to často nenávist vedle nenávisti, a to nemá na psychiku některých lidí, včetně mě, dobrý vliv. (žena, Bc.)

Přestala jsem trávit čas na Facebooku. (žena, Bc.)

Stal jsem se na těchto věcech méně závislý. (muž, Bc.) Kdysi jsem v sociálních sítich viděla spiše pozitiva brala jsem je jako odreagování, zpř́jemnění volného času (propojení s koníčky). Momentálně ... jim věnuji už minimum svého času ... vnímám je spíše negativně, jelikož lidi na soc. sítích jsou velmi negativně nastaveni. (žena, Bc.)

Když jsem si chtěla od informací a vtipů ohledně pandemie odpočinout, začala jsem daleko méně navštěvovat sociální sítě. Přetrvává to dodnes, vůbec mi nechybí. (žena, Bc.)

Větší důraz na informační hygienu v důsledku zkuše- 
ností z období pandemie platí i pro slovenské respondenty.

...som si vypla všetky upozornenia ... už nie je telefón organizátorom môjho vol'ného času. (žena, Bc.)

Po dvoch týždñoch karantény som urobila zásadný krok. Odstránila som si z telefónu Instagram, a aj Facebook, ktorý bol v mojom prípade hlavným zdrojom šírenia hoaxov, paniky, a prestala tak dopodrobna sledovat' aktuálne dianie týkajúce sa koronakrízy. (žena, Bc.)

Ked' som už nedokázal pozerat' na tol'ký počet šírenia falošných správ, ale aj tých pravdivých a sledovat' rozpory medzi l'ud'mi a ich neetické chovanie na internete, som sa rozhodol že sa odhlásim zo všetkých sociálnych sietí, obmedzím na internete stránky typu spravodajských médií. (muž, Bc.)

Jedna z respondentek $v$ rozhovoru naznačila logické vysvětlení vysokého objemu času na internetu i důvo$d y$, proč bude ona (a lidi obecně) věnovat sítím méně času.

To nesúvisí s koronou, ale s tým, že nechodím do práce a na siete mám viac času... Určite budem menej používat' sociálne siete, ked'že na to nebudem mat' tol'ko času. (žena, Mgr.)

\section{SHRNUTÍ A DISKUSE}

$\checkmark$ metodologii našeho výzkumu byl triangulační př́istup důležitým principem. Ve dvou zemích jsme realizovali tři výzkumné sondy, které přinesly analogické až identické výsledky. Domníváme se, že to zásadně zvyšuje relevanci a pravdivost těchto zjištění. Celá naše metodologie byla založena na sebereflexi respondentů - studentů vysokých škol. Nezkoumali jsme reálný průběh informačně-mediálních aktivit (jak by jej ukázala např́klad kvantitativní data o objemu hodin na sociálních sítích či počtu návštěv webových stránek), ale pocity, dojmy a názory mladých lidí. Domníváme se, že pandemie COVID-19 a související dění se stanou pro zkoumanou generaci zlomovým kulturně-civilizačním fenoménem, a proto jsme zkoumali, co pravděpodobně vstoupí do kolektivní paměti této generace.

Krátkodobou změnou v informačním chování studentů byl prudký nárůst zájmu o aktuální zdravotnické a politicko-společenské informace spojený $s$ príklonem $k$ tradičním masmédiím (televize, online deníky) $v$ průběhu první vlny pandemie. Postupně však tento zájem vyprchal, až se vrátil na předpandemickou úroveň. Paralelně s klesajícím zájmem o aktuální informace rostlo u studentů i znechucení ze sociálních síti, které se postupně stávaly nekontrolovatelnou arénou šíření hoaxů a polopravd. I když objem času tráveného na sociálních sítích nejdřív rostl, značná část studentů si uvědomila, že musí tento čas omezit. Budoucí šetření v postpandemickém období by mohlo ukázat, zda a do jaké míry se jim to i dlouhodobě podařilo.

Studenti si rovněž na př́kladu distančního online vzdělávání uvědomili, že technologicky nezprostředkovaný mezilidský kontakt má svůj psychohygienický význam i své praktické výhody. Obecně pocitovaný problém soustředit se na přednášky či semináře v prostředí domova možná této generaci přinese i zkušenost využitelnou v budoucnosti při kritickém uvažování o práci na dálku a home office.

\section{ZÁVĚRY}

Výzkum ukázal možnosti srovnání zkušeností studentů z různých zemí, které jsou navzdory upravené metodě, časovém odstupu a různé míre záběru respondentů velmi podobné. Dá se proto předpokládat, že celosvětová zkušenost s pandemií zasáhla mladé lidi z podobných podmínek velmi obdobně. Zejména s ohledem na využití těchto zkušeností při prípravě dalšího průběhu výuky knihovnictví na Slezské univerzitě, je třeba také poukázat jak na výhody online výuky, tak na její subjektivně pocitovanou zvýšenou náročnost. Vzhledem k tomu, že stávající podmínky i vybavení už umožňují naplno využívat předností distančních prostředků vzdělávání, kontaktní forma výuky je a měla by zůstat dominantní formou, a to také s ohledem na společenský a sociální rozměr, který osobní přítomnost na výuce přináší. Nic však nebrání tomu, oba přístupy ve vhodném poměru i do budoucna kombinovat; je však třeba zvláště zohlednit, že online výuku studenti vnímaji většinově jako velmi náročnou na soustředění, a adekvátně upravit formu i zvolené prostředky. Zcela odlišný je přitom potenciál distanční výuky u přednášky pedagoga, přednášky pozvaného hosta, semináře s diskusí a praktického cvičení.

Například v případě formátu, kdy se výuky účastní pozvaní hosté, online forma umožnila účast předních odborníků, kteří by se jinak nemohli nebo nebyli ochotni zúčastnit (Dombrovská 2021).

Výsledky výzkumu a srovnávacího výzkumu mezi českým a slovenským prostředím také otevírají možnosti sběru dalších dat, zejména tedy rozšíření záběru respondentů na české straně, at' už na jedné fakultě nebo v přesahu k jiným fakultám, resp. školám, a hloubkové rozhovory s vybranými respondenty. Rovněž je možné na výzkumy v obou zemích dále navázat dalším kolem 
dotazování. Časový odstup od bezprostředních událostí, které provázely lockdowny na jaře 2020, na podzim 2020 a na jaře 2021 však postupně způsobuje menší autenticitu výpovědí, menší zaujetí pro sdílení zkušeností a také jistý filtr u těch zkušeností a názorů, které jsou studenti ochotni sdílet. V tuto chvíli ještě nelze předvídat, co nás čeká $v$ akademickém roce 2021/2022, můžeme však už alespoň vycházet ze zkušeností, které nám výzkumy v České republice i na Slovensku přinesly a studentům vysokoškolskou výuku $s$ ohledem na znalost překážek na jejich straně více zpřistupnit. A také podpořit jejich informační chování mimo výuku, zejména uvědomování si existence zvýšené míry dezinformací, zvýšenou nutnost ověřování zdrojů i škodlivost nadměrného používání sociálních sítí.

\section{Bibliografie:}

Akademie věd České Republiky. 2020a. Vysokoškolští studenti během první vlny pandemie koronaviru. Dostupné z:

https://www.soc.cas.cz/aktualita/vysokoskolsti-studenti-behem -prvni-vlny-pandemie-koronaviru

Akademie věd České republiky. 2020b. Tři R už nestačí. Psychologický ústav Akademie věd přidává další. Dostupné z:

http://www.psu.cas.cz/cs/dalsi-informace/aktuality/Tri-R-uz-nestaci.-Psychologicky-ustav-Akademie-v ed-pridava-dalsi/

BOČÁK, Michal. 2009. Diskurz: neurčitá cesta kulturálnych, mediálnych a komunikačných štúdií do centra svojho záujmu. In: Kultura-Média-Komunikace. Roč. 1, č. 1, s. 117-146. ISSN 1804-0365. DOMBROVSKÁ, Michaela. 2021. Opavský knihovník a Hyde Park informačních profesionálů. In: Duha: Informace o knihách a knihovnách z Moravy [online]. Roč. 35, č. 2. ISSN 1804-4255. Dostupné z: http://duha.mzk.cz/clanky/opavsky-knihovnik-hyde-park-informacnich-profesionalu-v-opave

ELO, Satu a Helvi KYNGÄS. 2008. The qualitative content analysis process. In: Journal of Advanced Nursing. Roč. 62, č. 1, s. 107-115. ISSN 1365-2648.

GLASDAM, Stinne a Sigrid STJERNSWÄRD. 2020. Information about the COVID-19 pandemic - A thematic analysis of different ways of perceiving true and untrue information. In: Social Sciences \& Humanities Open [online]. Roč. 2, č. 1. ISSN 2590-2911. Dostupné z: https://www.sciencedirect.com/science/article/pii/ $\underline{\mathrm{S} 2590291120300796}$

GUO, Jinchi a Jie HUANG. 2021. Information literacy education during the pandemic: the cases of academic libraries in Chinese top universities. In: The Journal of Academic Librarianship [online]. Roč. 47, č. 4. ISSN 0099-1333. Dostupné z:

https://www.sciencedirect.com/science/article/abs/pii/ S0099133321000549

KAPPE a kol. 2021. Student life in time of corona. Dostupné $z$ : https://zenodo.org/record/3944727\#.YSf6604zY2w
KIRÁLY, Orsolya. 2020. Preventing problematic internet use during the COVID-19 pandemic: Consensus guidance. In: Comprehensive Psychiatry [online]. Č. 100. ISSN 0010-440X. Dostupné na: https:// www.ncbi.nlm.nih.gov/pmc/articles/PMC7215166/

Ministerstvo školství, mládeže a tělovýchovy. 2021. Anketa mezi pracovníky a studenty VŠ o dopadech pandemie. Dostupné z: https://www.msmt.cz/vzdelavani/vysoke-skolstvi/anketa-mezi -akademickymi-pracovniky-a-studenty- vysokych-skol

Národní ústav duševního zdraví. 2021. V důsledku pandemie covid-19 se s duševním onemocněním potýká téměř každý třetí dospělý: podporu nabídne nový web. Dostupné z:

https://www.nudz.cz/v-dusledku-pandemie-covid-19-se-s-dusevnim-onemocnenim-potyka-temer-kazdy-treti-dospely-podporu -nabidne-novy-web/

RABIEE-KHAN, Fatemeh a Karolina BIERNAT. 2021. Student well -being during the first wave of COVID-19 pandemic in Birmingham, UK. Dostupné z: https://zenodo.org/record/4572408\#.YSf7RI$\underline{4 z Y 2 W}$

RANKOV, Pavol. 2021a. Informačná gramotnost', sociálne siete a pandémia. In: Knižnica [online]. Roč. 22, č. 1, s. 6-11. ISSN 13360965. Dostupné z:

https://www.snk.sk/images/Edicna cinnost/Casopis Kniznica/2021/2021 0423 Kniznica 012021 komplet.pdf

RANKOV, Pavol. 2021b. Informačné správanie a informačná gramotnost' mladej generácie $v$ čase pandémie COVID-19. In: Knižnica [online]. Roč. 22, č. 1, s. 12-21. ISSN 1336-0965. Dostupné z: https://www.snk.sk/images/Edicna cinnost/Casopis Kniznica/2021/2021 0423 Kniznica 012021 komplet.pdf

RIEHM, Kira E. a kol. 2020. Associations between media exposure and mental distress among U.S. adults at the beginning of the COVID-19 pandemic. In: American Journal of Preventive Medicine [online]. Roč. 59, č. 5, s. 630-638. ISSN 1873-2607. Dostupné na: https://europepmc.org/article/pmc/pmc7351429

SKARPA, Paraskevi El. a Emmanouel GAROUFALLOU. 2021. Information seeking behavior and COVID-19 pandemic: a snapshot of young, middle aged and senior individuals in Greece. In: International Journal of Medical Informatics [online]. Roč. 150. ISSN 1386-5056. Dostupné z: https://www.sciencedirect.com/science/ article/abs/pii/S1386505621000915

SOROYA, Saira Hanif. a kol. 2021. From information seeking to information avoidance: understanding the health information behavior during a global health crisis. In: Information Processing \& Management [online]. Roč. 58, č. 2. ISSN 0306-4573. Dostupné z: https:// www.sciencedirect.com/science/article/pii/S030645732030933X SUPERIO, Daryl L. a kol. 2021. The information-seeking behavior and levels of knowledge, precaution, and fear of college students in Iloilo, Philippines amidst the COVID-19 pandemic. In: International Journal of Disaster Risk Reduction [online]. Roč. 62. ISSN 2212-4209. Dostupné z: https://www.sciencedirect.com/science/ article/pii/S2212420921003757 